Cakrawala Dini: Jurnal Pendidikan Anak Usia Dini | p-ISSN 2087-I317 | e-ISSN 2621-8321

Vol. 9. No.2 November 2018 | Hal I60-170

\title{
PENGEMBANGAN MEDIA INTERAKTIF DALAM PENGENALAN KATA BERMAKNA PADA ANAK
}

\author{
Nuri Cahyati ${ }^{1}$, Syafdaningsih, Rukiyah \\ Program Studi Pendidikan Anak Usia Dini, FKIP Universitas Sriwijaya
}

\begin{abstract}
The purpose of this study is to produce a interactive media in meaningful word recognition. The development of interactive media in meaningful word recognition using a combination of ADDIE development model and Tessmer evaluation. The ADDIE development model consists of five stages, namely the analysis, design, development, implementation and evaluation phase. At the evaluation stage, the formative evaluation proposed by Tessmer consists of stages, namely self evaluation stage, expert review, oneto-one evaluation, small group evaluation. grade collection techniques used interviews, vadidation sheets, and observations. Experimental results obtained the average score of the results of the assessment of interactive media in meaningful word recognition experts obtained $3.56 \%$ results and material experts of $3.81 \%$ to obtain an average of $3.68 \%$ (very valid category). The one to one evaluation stage was conducted by three students who used picture book of animals with a favorite theme obtained average $75 \%$ (practical) children observation result. The small group evaluaion stage was carried out by nine students who used the favorite animal-themed picture books obtained by an average $79.16 \%$ (practical) children's observation result, the field test stage was not performed because it only tested the validity and practicability level, not the potential effects of the use illustrated Interactive media products. Of all the stages that have been done then it can be concluded that the interactive media in meaningful word recognition declared valid and practical for the child.
\end{abstract}

Keyword: Development Interactive media, meaningful word recognition, 5-6 years old .

\begin{abstract}
Abstrak: Penelitian ini bertujuan untuk mengembangkan media interaktif dalam pengenalan kata bermakna. Pengembangan media interaktif dalam pengenalan kata bermaknaini menggunakan kombinasi model pengembangan ADDIE dan evaluasi Tessmer. Model pengembangan ADDIE terdiri dari lima tahap, yaitu tahap analisis, perancangan, pengembangan, implementasi, dan tahap evaluasi. Pada tahap evaluasi dilakukan evaluasi formatif yang dikemukakan oleh Tessmer terdiri dari tahap, yaitu tahap self evaluation, expert review, one-to-one evaluation, small group evaluation. Teknik pengumpulan data menggunakan wawancara, lembar validasi, dan observasi. Hasil expert review diperoleh nilai rata-rata hasil penilaian dari media interaktif dalam pengenalan kata bermakna oleh ahli media didapatkan hasil 3,56 \% dan ahli materi sebesar 3.81\% sehingga diperoleh rata-rata sebesar 3,68\% (kategori sangat valid). Tahap one to one evaluation dilakukan oleh tiga orang siswa yang menggunakan media interaktif dalam pengenalan kata bermakna didapatkan rata-rata hasil observasi anak $75 \%$ (praktis). Tahap small group evaluaion dilakukan oleh sembilan orang siswa yang menggunakan media interaktif dalam pengenalan kata bermakna didapatkan rata-rata hasil observasi anak $79.16 \%$ (praktis), tahap field test tidak dilaksanakan dikarenakan hanya menguji tingkat kevalidan dan kepraktisan, tidak sampai pada efek potensial dari penggunaan produk media interaktif. Dari semua tahap yang telah dilakukan maka dapat disimpulkan bahwa media interaktif dalam pengenalan kata bermakna dinyatakan valid dan praktis bagi anak
\end{abstract}

Kata Kunci: Pengembangan Media Interaktif, pengenalan kata bermakna, usia 5-6 tahun.

\footnotetext{
'Mahasiswa PGPAUD, Universitas Sriwijaya, Email: nuricahyati22回gmail.com
} 


\section{PENDAHULUAN}

Dalam pertumbuhannya masa kanak-kanak adalah masa ke emasan, yang biasanya disebut dengan "Golden Age". Pendidikan anak usia dini adalah upaya pembinaan yang dilalui oleh anak sejak dari lahir hingga usia enam tahun yang dilakukan melalui pemberian pendidikan untuk membantu pertumbuhan dan perkembangan jasmani dan rohani agar anak siap dalam memasuki pendidikan selanjutnya Peraturan Pemerintahan Nomor 146 Tahun 2014.

Mansur dikutip Madyawati (2016:2) memaparkan bahwa Pendidikan Anak Usia Dini merupakan salah satu bentuk penyelenggaraan pendidikan yang terfokus pada arah pertumbuhan dan enam perkembangan yaitu: perkembangan moral dan agama, perkembangan fisik yaitu koordinasi motorik kasar dan halus, kecerdasan atau kognitif yaitu daya piker dan daya cipta, sosial emosional yaitu sikap dan emosi, bahasa dan komunikasi, sesuai dengan keunikan dan tahap-tahap perkembangan berdasarkan kelompok usia yang telah dilalui oleh anak.

Salah satu aspek yang dikembangkan ditaman kanak-kanak adalah per-kembangan bahasa. Perkembangan bahasa pada anak usia dini merupakan salah satu fokus perkembangan yang tidak dapat dipisahkan dalam kegiatan di taman kanak-kanak. Menurut Chaer dan Agustina dikutip Yanti,dkk (2016:1) bahasa adalah alat untuk berinteraksi dalam arti alat untuk menyampaikan pikiran, gagasan, konsep atau perasaan. Dalam kehidupan sehari-hari bahasa sangatlah penting untuk berkomunikasi, Menurut Madyawati (2016:126) kecerdasan berbahasa disebut juga dengan kecerdasan linguistik, yaitu kemampuan untuk menggunakan kata-kata secara efektif baik secara lisan maupun tulisan. Kecerdasan ini mencakup kepekaan terhadap arti kata, urutan kata, suara, ritme, dan intonasi dari kata yang diucapkan, termasuk kemampuan untuk mengerti kekuatan kata dalam mengubah kondisi pikiran dan menyampaikan informasi baik secara lisan maupun tulisan, lewat bahasa lisan maupun tulisan anak dapat mengucapkan dan menuliskan kata seperti nama sendiri nama orang lain dan nama-nama benda yang ada disekitarnya.

Berdasarkan hasil wawancara yang telah peneliti lakukan pada Tiga TK yang ada di Palembang yakni pada hari pertama di PAUD Handayani Kelompok B pada bulan januari 2018 diperoleh informasi dari guru, ibu Tri Sunarti,S.Pd, media yang pernah digunakan dalam pengenalan huruf dan kata bermakna hanya menggunakan media seperti poster huruf, kartu huruf bergambar, huruf yang digunting kemudian diberi perekat, dan anak menyusun huruf menjadi kata pada papan flannel/Styrofoam kemudian merekatkan abjad pada flannel/Styrofoam tersebut. pada wawancara hari ke dua di TK IT Harapan Bunda pada bulan Februari 2018 peneliti memperoleh informasi dari ibu Sri Yati Ningsih,S.Pd.AUD, media yang digunakan dalam pengenalan huruf dan kata berupa buku, kartu huruf bergambar, dan poster huruf. kemudian pada hari ke tiga di PAUD Chatya Manis pada bulan Februari 2018 diperoleh infomasi dari ibu Kiapmawati,S.Pd media pembelajaran yang digunakan dalam pengenalan kata bermakna berupa buku, poster gambar, dan alat permainan edukatif seperti balok huruf.

Dari ketiga informasi yang peneliti dapatkan di taman kanak-kanak tersebut media poster huruf dan kartu huruf bergambar memang sering digunakan sebagai media pembelajaran. hal ini menyebabkan peserta didik cepat bosan saat pembelajaran berlangsung dikarenakan media yang digunakan monoton. Untuk mewujudkan pembelajaran yang aktif, diperlukan media alternatif yang dapat dijadikan media pembelajaran bagi anak usia dini, di 
era zaman yang lebih modern saat ini terutama dibidang Teknologi, sayang sekali jika tidak dimanfaatkan dengan baik, oleh karena itu peneliti membuat aplikasi berupa media pembelajaran interaktif, media interaktif itu sendiri memuat konten seperti teks, gambar bergerak, animasi, video, audio, dan video game yang dikemas lebih praktis. dengan media interaktif tersebut dapat membantu guru dalam mengajarkan pengenalan huruf dan menyusun kata bermakna, karena media interaktif praktis dan didalam media tersebut memuat banyak materi, sehingga mempermudah guru dalam penyampaian materi dan dapat menarik minat anak untuk belajar. Pembelajaran media interaktif sangat menarik, mudah dipahami dan tidak cepat membosankan dikarenakan Media Interaktif ini adalah teknik belajar sambil bermain yang dikemas sesuai untuk anak usia dini.

Henny Maryati Ambarita (2015) dalam penelitiannya yang berjudul "Pengembangan Multimedia Pembelajaran Interaktif Materi Berhitung Untuk Anak Kelompok A TK Teruna Bangsa" menyimpulkan bahwa Uji lapangan operasional field trial ditujukan kepada 15 anak kelompok A TK Teruna Bangsa Yogyakarta. Hasil ujicoba lapangan operasional menunjukkan bahwa multimedia pembelajaran interaktif yang dibuat oleh penulis memiliki nilai yang sangat baik dengan rata-rata 3,29. Penelitian pengembangan ini menghasilkan multimedia pembelajaran interaktif materi berhitung untuk anak kelompok A taman kanakkanak. Secara keseluruhan multimedia pembelajaran ini dikategorikan baik untuk digunakan dalam kegiatan pembelajaran berhitung untuk anak kelompok A Taman Kanak-Kanak.Multimedia pembelajaran interaktif materi berhitung ini dapat digunakan secara sendiri maupun secara bersama-sama di kelas.

Berdasarkan uraian diatas, maka peneliti mengembangkan penelitian dengan judul "Pengembangan Media Interaktif Dalam Pengenalan Kata Bermakna Pada Anak Kelompok B Usia 5-6 Tahun di PAUD Handayani Palembang".

\section{METODOLOGI PENELITIAN}

\section{Jenis Penelitian}

Jenis penelitian yang digunakan oleh peneliti adalah jenis penelitian pengembangan (Research Development). Pengembangan adalah suatu upaya atau proses untuk mengembangakan suatu produk baru, atau penyempurnaan suatu produk yang telah ada berupa media, materi, alat, atau strategi pembelajaran, yang berfungsi untuk mengatasi pembelajaran dikelas melalui kegiatan memvalidasi suatu produk dan bukan menguji teori.

Subjek dalam penelitian ini adalah media interaktif dalam pengenalan kata bermakna. Objek penelitian ini ialah anak Kelompok B1 di PAUD Handayani Palembang. Tahap uji coba one-to-one 3 anak, small group 9 anak.Penelitian ini dilakukan di PAUD Handayani Palembang Jl.Srijaya KM 5, pada anak usia 5-6 tahun semester genap tahun ajaran 2017/2018.

\section{Prosedur Penelitian}

Prosedur penelitian yang digunakan peneliti dalam penelitian pengembangan ini terdapat lima tahap yaitu tahap analisis, tahap perancangan, tahap pengembangan, tahap implementasi, dan tahap penilaian Tegeh dkk, (2014 : xvi).

Pada tahap analisis hal yang harus dilakukan yaitu menganalisis kebutuhan dan perkembangan anak dilakukan untuk mengetahui dan mengidentifikasi perkiraan kebutuhan dan perkembangan anak, yaitu dengan melihat karakteristik dan indikator pencapaian perkembangan bahasa anak untuk usia 5-6 tahun dan mendeskripsikan kriteria media yang baik untuk anak yang disesuaikan dengan tema yang ada di kurikulum.

Tahap perancangan diperlukan adanya penjabaran program pembelajaran 
yang didesain sehingga program tersebut dapat mencapai tujuan pembelajaran seperti yang diharapkan. Materi harus sesuai dengan analisis kebutuhan peserta didik yang telah didapat dan target yang akan dicapai oleh peneliti yaitu berupa penguasaan materi pembelajaran tentang pengenalan kata bermakna pada anak usia 5-6 tahun setelah menggunakan Media Interaktif Dalam Pengenalan Kata Bermakna Langkah-langkah dalam perancangan meliputi: (1) menentukan $\mathrm{KI}, \mathrm{KD}$, dan Indikator pem-belajaran, (2) membuat peta materi berdasarkan indikator, (3) merancang konsep poduk baru diatas kertas. Petunjuk penerapan desain atau pembuatan produk ditulis secara rinci, penyiapan Jabaran Materi, flowchart, dan storyboard/Naskah Media.

Langkah pengembangan meliputi kegiatan membuat dan memodifikasi media pembelajaran. Media yang dikembangkan yaitu Media Interaktif dalam mencapai tujuan pembelajaran pengenalan kata bermakna yang telah ditentukan. Pada tahap ini terdiri dari dua bagian yaitu paper based and computer based. Pada tahap paper based ini, desain media interaktif meliputi penyiapan Jabaran Materi, Garis Besar Isi Media, dan storyboard/naskah media yang sudah dilakukan pada tahap desain. Kemudian tahap kedua computer based, desain media interaktif pengenalan kata bermakna yang telah dibuat oleh peneliti dalam bentuk paper based diwujudkan dalam bentuk computer based yang terdiri dari pemrograman dasar, dan pembuatan desain grafis. Adapun program yang digunakan untuk mendesain media pembelajaran interaktif dalam pengenalan kata bermakna adalah Unity (Game engine).

Tahap terakhir, yaitu penilaian dengan melakukan pelaksanaan uji coba prototipe serta perbaikan berdasarkan masukan yang telah diperoleh, penilaian dilakukan dengan cara evaluasi formatif yaitu self evaluation, expert review, one- to-one evaluation, dan small goup evaluation.

Pada tahap self evaluation penilaian dilakukan oleh peneliti sendiri terhadap produk berupa media interaktif dalam pengenalan kata bermakna yang telah dikembangkan. Disini peneliti mengevaluasi sendiri media pembelajaran, untuk mengecek kembali apakah rumusan dan penjabaran materi serta evaluasi belajar telah benar dan tepat, proporsional desain tata letaknya dan apakah isi materinya sesuai dengan kriteria perkembangan bahasa anak usia 5-6 tahun.

Hasil produk (Prototipe 1) yang dikembangkan atas dasar self evaluation, diberikan kepada para ahli (expert) untuk divalidasi. Pada tahap ini, validator melihat dan mengevaluasi desain produk yang telah dibuat. Uji validitas yang dilakukan adalah uji validitas content (materi) dan desain media interaktif. Hasil validasi yang berupa tanggapan/komentar dan saran-saran pada lembar validasi akan dijadikan dasar untuk merevisi media interaktif dalam pengenalan kata bermakna (prototipe 1).

Pada tahap One-To-One

Evaluation ini produk buku cerita bergambar bertema binatang kesayangan diuji cobakan pada anak. Peneliti memilih tiga orang anak secara acak untuk mewakili populasi target yaitu anak dengan kemampuan rendah, sedang, dan tinggi. Anak tersebut diberikan pembelajaran dengan prototipe 1 yang sudah direvisi.

Pada saat proses pembelajaran anak akan diobservasi melalui lembar observasi yang telah disediakan untuk melihat dan menilai secara langsung tingka atau proses terjadinya suatu pembelajaran dengan menggunakan prototipe 1. Hal ini dilakukan dengan tujuan untuk melihat kepraktisan media interaktif tersebut dari sudut pandang anak. Hasil observasi anak tersebut akan dijadikan dasar untuk merevisi produk 
(prototipe 1) sehingga menghasilkan prototipe 2.

Dan terakhir ialah tahap small group evaluation diujicobakan pada kelompok kecil anak yang terdiri dari 9 orang. Selanjutnya, anak diberikan pembelajaran dengan prototipe 2 yang sudah direvisi. Pada proses pembelajaran, anak akan diobservasi kembali untuk melihat dan menilai secara langsung proses terjadinya suatu pembelajaran dengan menggunakan media interaktif dalam pengenalan kata bermakna (prototipe 2) yang digunakan.

\section{Teknik Pengumpulan Data}

Adapun teknik pengumpulan data yang digunakan dalam penelitian ini adalah sebagai berikut. Wawancara merupakan pertemuan dua orang untuk bertukar informasi melalui Tanya jawab. Peneliti melakukan wawancara guna memperoleh data awal untuk menjelaskan masalah yang terjadi di lapangan yang harus peneliti selesaikan. Pada teknik ini peneliti melakukan wawancara ke tiga TK yang berbeda yang ada di Pelembang guna memperloleh data yang akurat mengenai media interaktif dalam pengenalan kata bermakna. Sehingga peneliti dapat mengetahui kendala-kendala yang dihadapi guru dan anak dala proses pembelajaran di sekolah. media apa yang sering dipakai dalam peroses pembelajaran dan menggali informasi tentang apakah perlu media interaktif dalam pengenalan kata bermakna yang akan dikembangkan untuk anak usia 5-6 tahun sebagai media pembelajaran yang menarik sesuai bagi anak usia 5-6 tahun.

Walkthrough merupakan teknik pengumpulan data yang melibatkan beberapa ahli untuk mengevaluasi produk sebagai dasar untuk merevisi produk awal prototipe 1. Instrumen pengumpul data pada teknik ini adalah dengan menggunakan lembar validasi yang diberikan kepada ahli atau validator. Data yang dikumpulkan pada lembar validasi ini adalah berupa tanggapan dan saransaran yang menjadi dasar peneliti untuk melakukan revisi pada produk awal/prototipe.

Data dari hasil validasi oleh ahli kemudian didiskusikan dengan ahli itu sendiri untuk mendapatkan kejelasan informasi hasil validasi produk, sehingga peneliti bisa menggunakan data hasil validasi tersebut sebagai acuan untuk merevisi produk/prototipe sampai dinyatakan layak untuk diujicobakan. Dalam media interaktif dalam pengenalan kata bermakna proses validasi ahli meliputi validasi materi dan media. Adapun kisi-kisi intrumen validasi materi dan media dapat dilihat pada Tabel 1 dan 2 di bawah ini.

Tabel 1 Kisi-Kisi Instrumen Validasi Content/ Materi

\begin{tabular}{|l|l|l|}
\hline No & Indikator & Item \\
\hline 1 & $\begin{array}{l}\text { Kesesuaian materi } \\
\text { dengan kurikulum }\end{array}$ & $1,2,3,4$ \\
\hline 2 & $\begin{array}{l}\text { Kesesuaian visual } \\
\text { (teks, gambar, audio, } \\
\text { animasi) dengan } \\
\text { materi }\end{array}$ & $5,6,7,8$ \\
\hline 3 & $\begin{array}{l}\text { Kesesuaian dengan } \\
\text { bahasa yang } \\
\text { digunakan y yan dengan }\end{array}$ & $9,10,11,12$ \\
\hline 4 & $\begin{array}{l}\text { Kesesuaian anak } \\
\text { karakteristik 13,14,15,16 } \\
\text { usia 5-6 tahun }\end{array}$ \\
\hline
\end{tabular}

(Modifikasi Permendikbud No.137 dan Wiyani, 2014)

Tabel 2 Kisi-Kisi Instrumen Validasi Desain Produk

\begin{tabular}{|l|l|l|}
\hline No & Indikator & Item \\
\hline 1 & Desain tampilan & $1,2,3,4$ \\
\hline 2 & Penyajian & $5,6,7,8$ \\
\hline 3 & $\begin{array}{l}\text { Penggunaan font } \\
\text { (jenis dan ukuran } \\
\text { huruf) }\end{array}$ & $9,10,11,12$ \\
\hline 4 & $\begin{array}{l}\text { Tampilan pada layar } \\
\text { dan suara }\end{array}$ & $13,14,15,16$ \\
\hline
\end{tabular}

(Modifikasi Wati2016 dan Badriyah 2015)

Observasi sebagai suatu kegiatan yang dilakukan peneliti untuk mencatat perkembangan bahas peserta didik dengan bantuan instrumen-instrumen Pada 
penelitian ini, untuk mendapatkan data observasi dilakukan dengan cara melihat dan menilai secara langsung aktivitas dan tingkah laku anak selama proses pembelajaran dalam penggunaan media interaktif dalam pengenalan kata bermakna. Observasi dilakukan pada saat pra-penelitian, tahap one-to-one, dan small group apakah sudah berhasil dalam penggunaan media interaktif dalam pengenalan kata bermakna.Setelah itu hasil observasi dicatat oleh peneliti pada lembar observasi yang telah disediakan dengan kisi-kisi yang dapat dilihat pada Tabel 3 di bawah ini.

Tabel 3 Kisi-Kisi Instrumen Observasi Penilaian Aktivitas Anak Terhadap Penggunaan Media Interaktif Dalam Pengenalan Kata Bermakna

\begin{tabular}{|c|c|c|}
\hline No & Indikator Kegiatan & Nomor \\
\hline 1 & $\begin{array}{l}\text { - Menunjukkan hubungan } \\
\text { antara bunyi dan bentuk } \\
\text { huruf. }\end{array}$ & 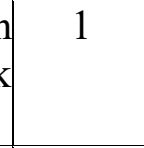 \\
\hline 2 & $\begin{array}{l}\text { Menyebutkan suara } \\
\text { huruf awal dari nama } \\
\text { benda-benda yang ada } \\
\text { disekitarnya. }\end{array}$ & 2 \\
\hline
\end{tabular}

(Permen No.137 2014)

\section{TeknikAnalisis Data}

Hasil wawancara yang telah didapat dari ketiga guru TK yang berada di Palembang digunakan pada latar belakang untuk mengetahui tentang perlunya media interaktif dalam pengenalan kata bermakna yang dikembangkan untuk anak usia 5-6 tahun kemudian hasil dari wawancara akan disimpulkan secara deskriptif dan dibuat menjadi catatan lapangan. Lembar hasil wawancara terdapat pada lampiran 1.

Hasil walkthrough dengan ahli dianalisis secara deskriptif sebagai masukan untuk merevisi media. Masukan tersebut dituliskan pada lembar validasi. Lembar validasi yang diberikan kepada ahli dalam bentuk skala likert. Sugiyono (2017: 165) Skala Likert dengan menggunakan empat kategori jawaban yaitu Sangat Baik (SB), Baik (B), Tidak Baik (TB), dan Sangat Tidak Baik (STB) seperti terlihat pada Tabel 4 sebagai berikut.

Tabel 4 Kategori Nilai Validasi Materi dan Media

\begin{tabular}{|l|l|}
\hline Kategori Jawaban & Skor Pernyataan \\
\hline Sangat Baik & 4 \\
\hline Baik & 3 \\
\hline Tidak Baik & 2 \\
\hline Sangat tidak Baik & 1 \\
\hline \multicolumn{2}{|l|}{ Modifikasi Arikunto, 2015:41) }
\end{tabular}

Hasil validasi dari validator disajikan dalam bentuk tabel. Selanjutnya dicari rata-rata skor tersebut dengan menggunakan rumus sebagai berikut: $\mathrm{x}=\frac{\sum X}{N}$

(Darmadi, 2014: 343)

Ket :

$\mathrm{X}=$ Nilai rata-rata

$\sum X=$ Jumlahnilai data

$\mathrm{N}=$ Banyaknya data

Selanjutnya rata-rata yang didapatkan disesuai-kan dengan kategori seperti yang terlihat pada Tabel 5 berikut ini.

Tabel 5 Kategori Tingkat Kevalidan Materi dan

\begin{tabular}{|l|l|}
\hline \multicolumn{2}{|c|}{ Media } \\
\hline $3,25-4,00$ & Kategori \\
\hline $2,50-3,24$ & Sangat Valid \\
\hline $1,75-2,49$ & Valid \\
\hline $1,00-1,74$ & Tidak Valid \\
\hline
\end{tabular}

Hasil observasi terhadap anak selama ujicoba pada tahap one-to-one evaluation, small group evaluation digunakan untuk melihat tingkah laku anak pada saat proses pembelajaran menggunakan media interaktif dalam pengenalan kata bermakna ini. Data hasil obsevasi disajikan dalam bentuk tabel, kemudian menghitung nilai hasil observasi dengan menggunakan rumus sebagai berikut.

$$
\begin{aligned}
& \text { Nilai Persentase } \\
& =\frac{\text { Skor Perolehan }}{\text { Skor Maksimal }} \times 100 \%
\end{aligned}
$$


Nilai observasi dikonversikan ke dalam kategori yang ditetapkan seperti pada Tabel 6 dan 7 di bawah ini.

Tabel 6 Nilai Kepraktisan Terhadap Penggunaan Media Interaktif Dalam Pengenalan Kata Bermakna Pada Anak Usia 5-6 Tahun

\begin{tabular}{|l|l|}
\hline Rata-Rata & Kategori \\
\hline 4 & BSB \\
\hline 3 & BSH \\
\hline 2 & MB \\
\hline 1 & BB \\
\hline
\end{tabular}

(Modifikasi, Arikunto 2015: 41)

Tabel 7 Kategori Nilai Hasil Observasi Anak Terhadap Penggunaan Media Interaktif Dalam Pengenalan Kata Bermakna

\begin{tabular}{|l|l|}
\hline Skor (\%) & Kategori \\
\hline $81-100$ & Sangat praktis \\
\hline $61-80$ & Paktis \\
\hline $41-60$ & Cukup praktis \\
\hline $21-40$ & Tidak praktis \\
\hline
\end{tabular}

(Modifikasi Hestari, dkk. 2016)

\section{HASIL PENELITIAN DAN PEMBAHASAN}

Penelitian Pengembangan ini memiliki tujuan yaitu untuk menghasilkan media interaktif dalam pengenalan kata bermakna pada anak usia 5-6 tahun yang valid dan praktis di PAUD Handayani Palembang. Dalam hal ini peneliti mengembangkan sebuah produk berupa media interaktif. Penelitian ini dilakukan pada tanggal 7 Mei 2017 hingga 9 Mei 2017 dengan subjek penelitian anak kelompok B di PAUD Handayani Palembang dan objek penelitian berupa media interaktif. Penelitian ini menggunakan kombinasi model pengembangan ADDIE dan model evaluasi formatif Tessmer. Model pengembangan ADDIE terdiri dari lima tahap yaitu tahap Analysis, tahap Design, tahap Development, tahap Implementation, dan tahap Evaluation. Pemilihan model pengembangan ADDIE dalam penelitian ini karena model pengembangan ADDIE merupakan salah satu model yang berorientasi pada produk khususnya untuk memproduksi media interaktif. Selanjutnya, untuk tahap evaluasi digunakan model evaluasi Tessmer yang terdiri dari lima tahap, yaitu tahap self evaluation, expert review, oneto-one evaluation, small group evaluation dan field test, namun pada tahap Field test tidak dilaksanakan karena penelitian yang dilakukan peneliti tidak menguji efek potensial anak melainkan mengujikan sebuah kevalidan dan kepraktisan produk yang dikembangkan. Dalam penyampaian Materi pembelajaran pengenalan kata bermakna pada anak usia 5-6 tahun ini media yang digunakan konvensional, monoton, dan kurang bervariasi akibatnya anak kurang aktif dalam proses pembelajaran. Untuk itu peneliti mengembangkan media dalam proses pembelajaran yaitu berupa media interaktif dalam pengenalan kata bermakna pada anak usia 5-6 tahun sebagai media alternatif baru yang dikemas kedalam media yang lebih menarik bagi anak. Setelah melakukan tahap analisi kebutuhan, kemudian tahap selanjutnya peneliti melakukan tahap perancangan. Tahap perancangan terdiri dari menentukan Kompetensi Inti, Kompetensi Dasar, dan Indikator pembelajaran yang akan dicapai oleh anak saat menggunakan media interaktif yaitu Menunjukkan hubungan antara bunyi dan bentuk huruf, kemudian Menyebutkan suara huruf awal dari nama benda-benda yang ada disekitarnya. Kemudian merancang konsep produk baru diatas kertas. Petunjuk penerapan desain atau pembuatan produk ditulis secara rinci, penyiapan Jabaran Materi, flowchart, dan storyboard/Naskah Media. Setelah melakukan tahap perencanaan, kemudian tahap selanjutnya peneliti melakukan tahap pengembangan. Tahap pengembangan terdiri dari dua tahap yaitu paper based dan computer based . dari bentuk paper based kemudian diwujudkan dalam bentuk computer based yang terdiri dari pemrograman dasar, 
pembuatan grafis, dan desain. Adapun program yang digunakan untuk mendesain media interaktif dalam pengenalan kata bermakna adalah Unity (Game engine) Pada tahap ini juga peneliti menyiapkan perangkat evaluasi. Sebelum digunakan perangkat evaluasi terlebih dahulu dikonsultasikan dengan dosen pembimbing. Hasil dari tahap pengembangan ini adalah prototipe 1 .

Media interaktif dalam pengenalan kata bermakna pada anak usia 5-6 tahun yang telah dikembangkan kemudian divalidasi oleh para ahli expert review. Tahap expert review ini bertujuan untuk mengetahui materi dan desain media interaktif dalam pengenalan kata bermakna pada anak yang valid. Media interaktif dalam pengenalan kata bermakna pada anak usia 5-6 tahun divalidasi oleh ahli yaitu meliputi validasi content/materi yang dilakukan oleh ibu Mahyumi Rantina,M.Pd dan validasi ahli media yang dilakukan oleh ibu Dra.Rukiyah,M.Pd dalam memvalidasi media interaktif pengenalan kata bermakna pada anak usia 5-6 tahun. Prototipe 1 yang telah didesain kemudian dikonsultasikan dengan dosen pembimbing skripsi dan kemudian divalidasi oleh ahli. Dengan deskriptor yaitu (1) Kejelasan Kompetensi Inti (KI) (2) Kejelasan Kompetensi Dasar (KD) (3) Kesesuaian materi dengan kompetensi dasar (4) Kesesuaian materi dengan indikator pembelajaran (5) Kesesuaian gambar dengan animasi (6) Kesesuaian materi dengan gambar (7) Kesesuaian animasi dengan indikator pembelajaran (8) Kesesuaian gambar dengan indikator pembelajaran (9) Penggunaan kata sesuai dengan ejaan yang disempurnakan. (10) Kesesuaian kata yang digunakan (11) Kejelasan kata yang digunakan. (12) Konsep yang disampaikan jelas (13) Materi pengenalan kata sesuai dengan karakteristik anak usia 5-6 tahun (14) Kedalaman materi pengenalan kata (15) Kemudahan materi pengenalan kata untuk anak usia 5-6 tahun (16) Materi pengenalan kata yang disajikan mampu menarik perhatian anak. Dari keempat deskriptor tersebut ahli materi bisa memberikan skala penilaian dengan menggunakan empat kategori jawaban yaitu Sangat Baik (SB) dengan skor 4, Baik (B) dengan skor 3, Kurang Baik (KB) dengan skor 2, dan Tidak Baik (TB) dengan skor 1. Setelah memberikan skor pada masing-masing descriptor, kemudian skor tersebut dijumlahkan, dan untuk jumlah total skor yang didapat dari keempat indikator pada lembar validasi materi media interaktif pengenalan kata bermakna adalah 16. Skor indikator pertama pada Kesesuaian materi dengan kurikulum mendapat 16 ponit, indikator yang kedua pada Kesesuaian visual (teks, gambar, audio, animasi) dengan materi mendapat 15 point, kemudian pada indikator ketiga pada Kesesuaian bahasa yang digunakan mendapat 15 point, dan indikator yang terakhir pada Kesesuaian dengan karakteristik anak usia 5-6 tahun mendapat 15 point, jadi total perolehan skor dari keempat indikator yaitu 61 point. Secara keseluruhan, nilai rekapitulasi hasil dari validasi Expert Review pada validasi materi produk media interaktif dalam pengenalan kata bermakna pada anak usia 5-6 tahun sebesar 3,56 (kategori sangat valid), dan validator ahli media dalam pengenalan kata bermakna pada anak usia 5-6 tahun sebesar 3,81 (kategori sangat valid) sehingga didapat nilai rekapitulasi hasil validasi kedua ahli tersebut adalah 3,68 (kategori sangat valid). Dikatakan valid karena hasil hitung persentase karena apabila diinterpretasikan menurut Sugiyono dikutip Amri (2015) tingkat kevalidan materi dan media termasuk kedalam kategori sangat valid dan layak diuji cobakan rata-rata 3,25 - 4,00 (Sangat Valid), 2,50 - 3,24 (Valid), 1,75 - 2,49 (tidak valid), 1,00 - 1,74 (sangat tidak valid). Dengan demikian, media interaktif dalam pengenalan kata bermakna pada anak usia 5-6 tahun yang dikembangkan peneliti dapat digunakan pada tahap uji 
coba selanjutnya. Adapun beberapa komentar dari validator untuk revisi dari prototipe 1. Validasi media dilakukan oleh ibu Dra.Rukiyah,M.Pd berikut ini pendapat dari hasil melakukan validasi media (1) Beri reward pada penyusunan kata. Setelah anak selesai menyusun kata munculkan emotikon jempol dan suara "ya hebat, kamu berhasil", Tanggapan dari peneliti sudah diperbaiki. Selanjutnya ahli materi dilakukan oleh ibu Mahyumi Rantina,M.Pd berikut ini hasil validasi materi (1) pada menu bantuan dibuatkan tutorial masing-masing kegiatan, (2) petunjuk penggunaan (3) pada permainan huruf agar ada penilaian penyusunan kata bermakna ataupun bermain puzzle, tanggapan peneliti sudah diperbaiki. Selanjutnya, media interaktif dalam pengenalan kata bermakna pada anak usia 5-6 tahun yang telah divalidasi kemudian diujicoba pada tahap one-to-one evaluation.

Tahap one-to-one evaluation bertujuan untuk melihat kepraktisan prototipe 1 yang telah divalidasi oleh ahli. Dalam tahap ini melibatkan tiga orang anak dan mereka secara bersamaan menggunakan media interaktif dalam pengenalan kata bermakna pada anak usia 5-6 tahun. Tahap ini peneliti mendampingi guru dalam mengoprasikan media interaktif lalu anak mendengarkan dan menjawab pertanyaan yang diberikan oleh guru menunjukkan hubungan antara bunyi dan bentuk huruf, kemudian menyebutkan suara huruf awal dari nama benda-benda yang ada disekitarnya. Setelah anak menggunakan prototipe 1, peneliti mengobservasi anak pada saat pembelajaran yang bertujuan untuk melihat penilaian mereka terhadap prototipe1. Berdasarkan indikator yang sudah ditentukan yaitu (1) anak menunjuk-kan hubungan antara bunyi dan bentuk huruf, dengan deskripsi Anak dapat menunjukkan hubungan antara bunyi dan bentuk huruf dengan benar tanpa bantuan dengan skor 4, Anak dapat menunjukkan hubungan antara bunyi dan bentuk huruf dengan bantuan dengan skor 3, Anak mulai dapat menunjukkan hubungan antara bunyi dan bentuk huruf dengan skor 2, Anak tidak dapat menunjukkan hubungan antara bunyi dan bentuk huruf dengan skor 1, (2) anak Menyebutkan suara huruf awal dari nama benda-benda yang ada disekitarnya, dengan deskripsi Anak dapat Menyebutkan suara huruf awal dari nama benda-benda yang ada disekitarnya dengan benar tanpa bantuan dengan skor 4, Anak dapat Menyebutkan suara huruf awal dari nama benda-benda yang ada disekitarnya dengan bantuan dengan skor 3, Anak mulai dapat Menyebutkan suara huruf awal dari nama benda-benda yang ada disekitarnya dengan skor 2, Anak tidak dapat Menyebutkan suara huruf awal dari nama benda-benda yang ada disekitarnya dengan skor 1. (1) Peserta didik Fajri mewakili dari kelompok hasil belajar tinggi,mendapatkan skor 7 dengan nilai 87,5 (2) peserta didik Nabil mewakili dari kelompok hasil belajar sedang, mendapatkan skor 6 dengan nilai 75 (3) Putri mewakili kelompok hasil belajar rendah mendapatkan skor 5 dengan nilai 62,5. Jumlah total dari tahap ini adalah 225. Nilai persentase rata-rata hasil observasi anak terhadap penggunaan media interaktif dalam pengenalan kata bermakna pada anak usia 5-6 tahun pada tahap one-to-one evaluation sebesar $75 \%$ kategori berkembang sesuai harapan sehingga dapat disimpulkan bahwa penggunaan media interaktif dalam pengenalan kata bermakna pada anak usia 5-6 tahun pada tahap tergolong praktis. Hasil revisi dari prototipe 1 didapatkan prototipe 2.

Selanjutnya untuk melihat kepraktisan dalam penggunaan media interaktif dalam pengenalan kata bermakna pada anak usia 5-6 tahun dilakukan uji coba prototipe 2 pada anak dalam tahap small group evaluation. Tahap ini dilaksanakan untuk melihat kepraktisan protipe 2 . Uji coba prototipe 2 ini dilakukan dengan melibatkan 9 orang 
anak kelompok B di PAUD Handayani Palembang. Tahap ini peneliti mendampingi guru yang menjelaskan dalam menggunakan media interaktif tersebut lalu anak mendengarkan dan menjawab pertanyaan yang diberikan oleh guru seperti menunjukkan hubungan antara bunyi dan bentuk huruf, kemudian menyebutkan suara huruf awal dari nama benda-benda yang ada disekitarnya. Pada uji coba di tahap small group evaluation, anak diobservasi kembali. dengan indikator yang sudah ditentukan yakni (1) anak menunjukkan hubungan antara bunyi dan bentuk huruf, (2) anak Menyebutkan suara huruf awal dari nama benda-benda yang ada disekitarnya. Masing-masing indikator memiliki deskripsi yaitu (1) anak menunjuk-kan hubungan antara bunyi dan bentuk huruf, dengan deskripsi Anak dapat menunjukkan hubungan antara bunyi dan bentuk huruf dengan benar tanpa bantuan dengan skor 4, Anak dapat menunjukkan hubungan antara bunyi dan bentuk huruf dengan bantuan dengan skor 3, Anak mulai dapat menunjukkan hubungan antara bunyi dan bentuk huruf dengan skor 2, Anak tidak dapat menunjukkan hubungan antara bunyi dan bentuk huruf dengan skor 1, (2) anak Menyebutkan suara huruf awal dari nama benda-benda yang ada disekitarnya, dengan deskripsi Anak dapat Menyebutkan suara huruf awal dari nama benda-benda yang ada disekitarnya dengan benar tanpa bantuan dengan skor 4, Anak dapat Menyebutkan suara huruf awal dari nama benda-benda yang ada disekitarnya dengan bantuan dengan skor 3, Anak mulai dapat Menyebutkan suara huruf awal dari nama benda-benda yang ada disekitarnya dengan skor 2, Anak tidak dapat Menyebutkan suara huruf awal dari nama benda-benda yang ada disekitarnya dengan skor 1. (1) Fadil mendapat skor 5 dengan nilai 62,5 , (2) Sifa mendapat skor 7 dengan nilai 87,5 , (3) Abi mendapat skor 6 dengan nilai 75, (4) Putri mendapat skor 8 dengan nilai 100, (5) Nabil mendapat skor 8 dengan nilai 100, (6) Angga mendapat skor 5 dengan nilai 62,5 , (7) Bayu mendapat skor 6 dengan nilai 75, (8) Ari mendapat skor 6 dengan nilai 75, (9) Gendis mendapat skor 6 dengan nilai 75. Jumlah total seluruh skor yang diperoleh anak dari tahap ini adalah 712,5. Nilai rata-rata persentase hasil observasi tahap small group evaluation pada media interaktif dalam pengenalan kata bermakna pada anak usia 5-6 tahun $79.16 \%$ praktis, Dinyatakan praktis karena apabila diinterpretasikan menurut Kurniawati dikutip Agustina (2016) media pengenalan kata bermakna termasuk kedalam kategori praktis yakni nilai $81 \%$ - $100 \%$ (sangat praktis), $61 \%$ - $80 \%$ (praktis), 41\% - 60\% (cukup praktis) 21\% - $40 \%$ (tidak praktis) hal tersebut menunjukkan bahwa prototipe 2 yang dikembangkan peneliti sudah praktis.

Berdasarkan deskripsi dan analisis data hasil penelitian didapatkan hasil dari expert review yaitu bahwa produk pengembangan media interaktif dalam pengenalan kata bermakna yang dikembangkan sudah valid dan analisis dari one to one evaluation dan small group evaluation bahwa produk pengembangan media interaktif dalam pengenalan kata bermakna yang dikembangkan sudah praktis sehingga dapat digunakan sebagai media pembelajaran untuk anak usia 5-6 tahun.

\section{KESIMPULAN}

Hasil penelitian yang telah dilakukan oleh peneliti tentang pengembangan media interaktif dalam pengenalan kata bermakna pada anak usia 5-6 tahun dapat disimpulkan sebagai berikut :

1. Valid dinyatakan valid hal tersebut dilihat dari hasil validasi para ahli (expert review) yang terdiri dari ahli content/materi dan desain sehingga bahan ajar media interaktif dalam pengenalan kata bermakna pada anak usia 5-6 tahun dikatakan layak dan valid digunakan sebagai media pembelajaran dalam pengenalan kata 
bermakna pada anak usia 5-6 tahun. Adapun hasil dari rata-rata yang didapat pada tahap expert review sebesar 3,68 (kategori valid).

2. Praktis dinyatakan praktis karena berdasarkan hasil pada tahap one-toone evaluation pada penggunaan media interaktif dalam pengenalan kata bermakna nilai yang diperoleh dari anak yaitu 75\% kategori Praktis dan pada tahap small group evaluation $79.16 \%$ kategori Praktis hasil dari kedua tahap evaluasi dapat dinyatakan bahwa media interaktif dalam pengenalan kata bermakna pada anak usia 5-6 tahun yang dikembangkan oleh peneliti telah teruji kepraktikalitasnya.

\section{DAFTAR PUSTAKA}

Amri. Iful. Vol. 2 No. 1. (2015). Pengembangan pembelajaran ELearning Berbasis Web Untuk Mata Kuliah Pendahuluan Fisika Inti.

Arikunto,S. (2015). Dasar-Dasar Evaluasi Pendidikan Edisi 2.Jakarta: Bumi Aksara.

Badriyah. (2015). Efektifitas Proses Pembelajaran Dengan Pemanfaatan Media Pembelajaran.

Dhieni, Nurbiana,dkk. (2014). Metode Pengembangan Bahasa.Tangerang Selatan: Universitas Terbuka.

Henny,Maryati Ambarita (2015)."Pengembangan Multimedia Pembelajaran Interaktif Materi Berhitung Untuk Anak Kelompok A TK Teruna Bangsa". Universitas Negeri Yogyakarta.

Hestari, Selvira, dkk. (2016). Validitas, Kepraktisan, Dan Efektivitas Media Pembelajaran Papan Magnetik Pada Materi Mutasi Gen. 5(1). Jurnal Ilmiah Berkala Biologi.

Kementrian Pendidikan dan Kebudayaan RI. (2014). Buku Panduan Pendidik Kurikulum 2013 PAUD Anak Usia 5-6 Tahun. Jakarta.
Madyawati, Lilis. (2016). Strategi Pengembangan Bahasa. Jakarta: Prenadamedia Group.

Mulyati,Yeti dkk. (2015).Keterampilan Berbahasa Indonesia SD.Tangerang Selatan : Universitas Terbuka.

Sugiyono. (2015). Metodologi Penelitian dan Pengembangan. Bandung : Alfabeta

Tessmer,M. (1993). Planning and Conducting Formative Evaluation. London: Kogan Page.

Tegeh, I Made. Dkk. (2014). Model Penelitian Pengembangan. Yogyakarta:Graha Ilmu.

Permerintah Pendidikan dan Kebudayaan (2014). No.137 \& 146 Tentang Kurikulum 2013.

Wiyani,N.A. (2014). Psikologi Perkembangan Anak Usia Dini. Gava Media:Yogyakarta.

Wati, Rima. (2016). Ragam Media Pembelajaran. Jogjakarta : kata Pena.

Zainiyati. (2017). Pengembangan Media Pembelajaran Berbasis ICT. Jakarta: KENCANA 